\title{
Recent advances in vaccines and diagnostics against Middle East respiratory syndrome coronavirus
}

\author{
K. LEE ${ }^{1,2}$, J. H. NAM ${ }^{*}$ \\ 1Department of Biotechnology, The Catholic University of Korea, 43-1 Yeokgok 2-dong, Wonmi-gu, Bucheon, 14662, Korea; \\ ${ }^{2}$ Bio R\&D, SK bioscience, Seongnam, Gyeonggi-do, Korea
}

Received February 11, 2020; accepted March 16, 2020

\begin{abstract}
Summary. - Middle East respiratory syndrome coronavirus (MERS-CoV) is an RNA virus that causes severe respiratory disease. Since it was identified in 2012, approximately 2500 MERS cases with high mortality have been confirmed in 27 countries. Although most cases have occurred in the Middle East, an outbreak in South Korea in 2015 showed that MERS could be a global threat via human-to-human transmission. There is no licensed vaccine against MERS. Thus, early detection is the best way to limit the spread of this fatal disease. In this review, we focus on transmission, the infection process, and scientific efforts in vaccine development and diagnostics for MERS-CoV.
\end{abstract}

Keywords: Middle East respiratory syndrome coronavirus; epidemiology; virology; vaccine; diagnostics

\section{Introduction}

Middle East respiratory syndrome (MERS) is a serious respiratory disease caused by Middle East respiratory syndrome coronavirus (MERS-CoV). The virus was first isolated from a patient with pneumonia in Saudi Arabia in 2010 (Zaki et al., 2012). According to the World Health Organization (WHO), 2494 laboratory-confirmed cases and 858 deaths have been reported from 27 countries in the Middle East, Asia, North Africa, and Europe since 2012 (Fig. 1). MERS-CoV is an infectious pathogen with a high fatality rate $(\sim 35 \%)$, and most cases have occurred in the

"Corresponding author. E-mail: jhnam@catholic.ac.kr; phone: +82-2-2164-4917.

Abbreviations: $\mathrm{CD} 26$ = see DPP4; DPP4 = dipeptidyl peptidase 4 (CD26); ELISA = enzyme-linked immunosorbent assay; KSA = Kingdom of Saudi Arabia; MERS = Middle East respiratory syndrome; MERS-CoV = Middle East respiratory syndrome coronavirus; $\mathrm{MN}$ = microneutralization; $\mathrm{MVA}=$ modified vaccinia ankara; RBD = receptor binding domain; NAAT = nucleic acid amplification test; NSP = nonstructural protein; VLP = virus like particle; $\mathrm{WHO}=$ World Health Organization
Middle East peninsula. However, an outbreak of MERS in South Korea in 2015 demonstrated that MERS-CoV might be a global pandemic threat (Nishiura et al., 2016a,b; Park et al., 2015). However, there are no licensed vaccines or therapeutics against MERS-CoV. For this reason, early detection and diagnostics are crucial to avoid the spread of this deadly virus. In this review, we highlight the epidemiology and virology of MERS-CoV and discuss recent efforts to develop vaccines and diagnostic tools.

\section{Epidemiology of MERS-CoV}

MERS was first identified in 2012 in the Kingdom of Saudi Arabia (KSA). A male patient with acute pneumonia died as a result of respiratory and renal malfunction (Zaki et al., 2012). Sputum samples from the patient were negative for influenza, parainfluenza, respiratory syncytial virus, and adenovirus by indirect immunofluorescence assays (Zaki et al., 2012). However, PCR testing detected the presence of coronavirus, and sequencing confirmed that the virus belonged to lineage $C$ of the beta coronavirus genus; it was first named human coronavirus EMC (HCoV-EMC) (Zaki et al., 2012). 


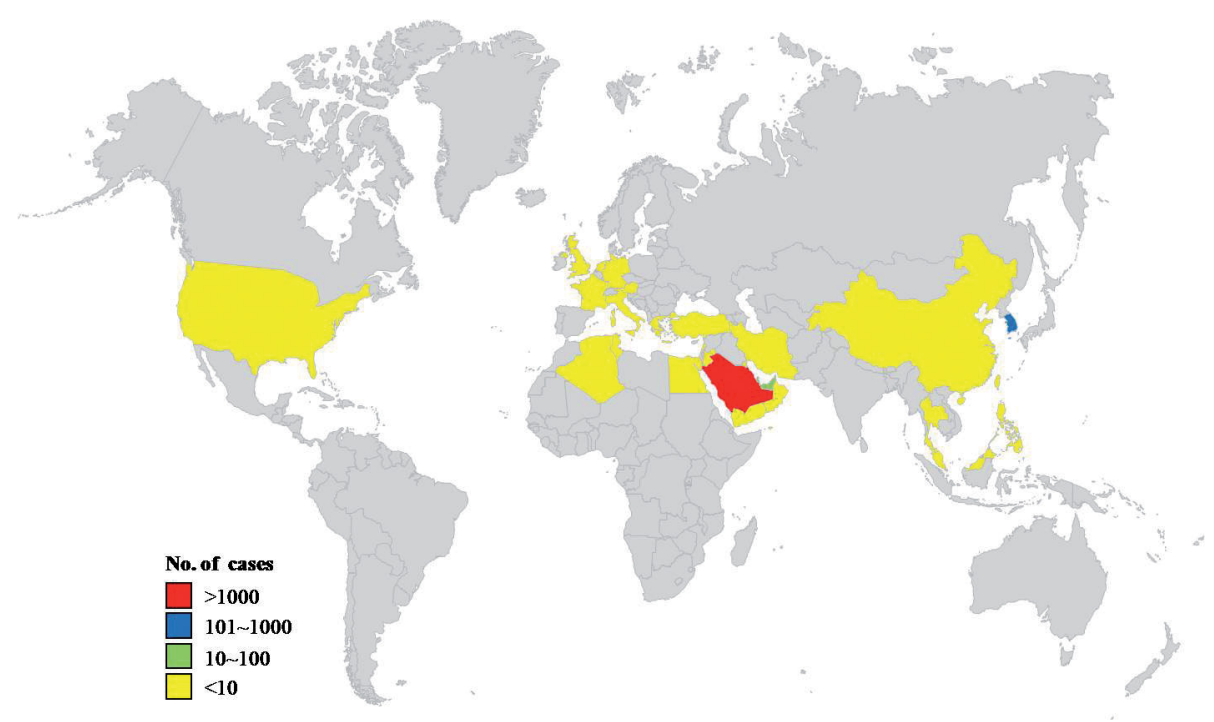

Fig. 1

Worldwide distribution of MERS cases

The majority of MERS cases reported have occurred in the KSA. As of November 2019, the WHO had confirmed 2102 cases in the KSA, including 780 deaths, for a mortality rate of $37.1 \%$. Outside the KSA, an unpredicted outbreak occurred in South Korea between May and July 2015 (Nishiura et al., 2016a, b). This outbreak included 186 cases and caused 36 deaths (Nishiura et al., 2016a,b). It was thought to be associated with individuals who had previously traveled in the Middle East (Nishiura et al., 2016a,b). The WHO and the Center of Disease Control and Prevention (CDC) reported that confirmed MERS cases occurred in 17 Middle Eastern countries and 10 countries outside the Middle East. MERS cases outside the Middle East occurred in people with a history of travel to the Arabian Peninsula.

Bats are assumed to be the origin reservoir of MERSCoV because the sequences of samples from various bats were closely related to MERS-CoV (Corman et al., 2014a). For example, the sequences of HKU4 bat coronavirus and MERS-CoV showed a high similarity in the receptor binding domain (RBD) of the $S$ protein. However, bats are not thought to be a direct source of MRES-CoV infection in humans because of the rarity of contact with bats.

Camels are considered to be an intermediary host of MERS-CoV. Serological tests on dromedary camels in the Middle East and Africa confirmed that they were positive for anti-MERS-CoV antibodies. Direct contact with camels might be responsible for animal-to-human transmission. For example, camel workers in the KSA were reported to be at high risk for MERS-CoV infection (Alshukairi et al., 2018), with possible routes of transmission including the consumption of camel milk, urine, or improperly cooked meat. These factors may explain why MERS-CoV transmission from camels to humans occurred especially in the Middle East. Human-to-human spread through nosocomial infection is another route of transmission. Late diagnosis might lead to rapid spread among hospital workers, family members, and other patients (Al-Abdallat et al., 2014; Assiri et al., 2013; Park et al., 2015). In South Korea, a lack of quarantine, failures in infection control, and "doctor shopping" resulted in an unexpectedly rapid spread (Kim et al., 2017). MERS-CoV has also spread within medical facilities in the Middle East (Assiri et al., 2013) and South Korea (Park et al., 2015).

\section{Virology of MERS-CoV}

Coronaviruses (CoVs) are enveloped, positive-sense, single-stranded RNA viruses with a large genome of 25-32 kilobases. CoVs belong to the Coronavirinae subfamily in the Coronaviridae family. There are four genera (alpha, beta, gamma, and delta $\mathrm{CoV}$ ) in the Coronavirinae subfamily, and beta CoVs are subdivided into four lineages (Wang et al., 2018). MERS-CoV belongs to lineage $\mathrm{C}$ of the beta CoVs (Chan et al., 2015b). Several bat coronaviruses, including NeoCoV, HKU4, and HKU5, are also lineage C viruses (Corman et al., 2014a; Ithete et al., 2013). Bats are considered a potential mammalian reservoir of MERS$\mathrm{CoV}$, and phylogeny studies of lineage $\mathrm{C}$ viruses suggest that MERS-CoV may have appeared in humans through genetic exchange in bats or camels (Corman et al., 2014a). 
(a)

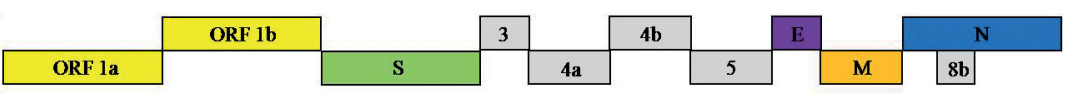

(b)

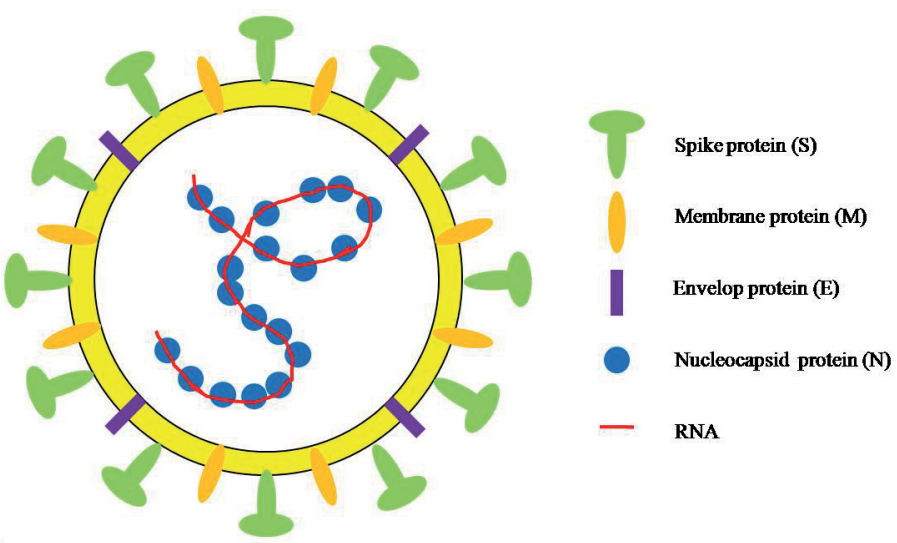

(c)

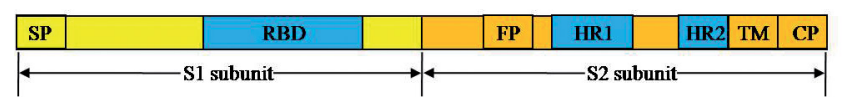

Fig. 2

Schematic structure of MERS-CoV

(a) MERS-CoV genome; (b) MERS-CoV virion and (c) $S$ protein.

The MERS-CoV genome is 30,119 nucleotides in length and composed of seven open reading frames (ORF1a, ORF1b, ORF3, ORF4a, ORF4b, ORF5, and ORF8b) and four structural genes encoding the spike (S), envelope (E), membrane $(\mathrm{M})$, and nucleocapsid $(\mathrm{N})$ proteins (Forni et al., 2017; Mackay and Arden, 2015) (Figure 2). ORFla and ORF1b encode polyproteins ppla and pplab, which are cleaved by viral protease to release 16 nonstructural proteins (NSPs). These proteins establish the replication-transcription complex. Each NSP has its role, including proteases (NSP3 and NSP5), primer-making activity and regulation of NSP12 (NSP7-NSP11), RNA polymerase (NSP12), and RNA modification(NSP13-NSP16) (Forni et al.,2017; Hagemeijer et al., 2012; Neuman et al., 2014).
The S protein plays a vital role in virus infection and host cell entry. It is composed of N-terminal S1 and Cterminal S2 subunits. The $\mathrm{S} 1$ subunit contains RBD that binds to the dipeptidyl peptidase 4 (DPP4; also known as CD26) of the host cell (Raj et al., 2013), causing endocytosis and cleavage of S1 and S2 by host protease (Millet and Whittaker, 2014; Qian et al., 2013; Yang et al., 2015). The S2 subunit mediates virus fusion with the host cell membrane followed by virus entry into the host cell. The $\mathrm{M}$ and $\mathrm{E}$ proteins are responsible for viral assembly, and the $\mathrm{N}$ protein is required for RNA synthesis.

DPP4 is broadly expressed on human cells in various tissues, including lung, kidney, small intestine, and liver (Widagdo et al., 2016). For this reason, many human cell

Table 1. The comparison of MRES-CoV vaccine platforms

\begin{tabular}{|c|c|c|c|}
\hline Vaccines & Antigen & Advantage & Disadvantage \\
\hline Viral vector vaccine & recombinant virus vector encoding $\mathrm{S}$ protein & robust immune response & risk of potential infection \\
\hline DNA vaccine & recombinant plasmid expressing $\mathrm{S}$ protein & low production cost & $\begin{array}{l}\text { risk of integration into host } \\
\text { genome }\end{array}$ \\
\hline Subunit vaccine & recombinant S protein or $\mathrm{RBD}$ & good safety profile & $\begin{array}{l}\text { relatively low } \\
\text { immunogenicity }\end{array}$ \\
\hline VLP vaccine & $\begin{array}{l}\text { nanoparticles mimicking native virus } \\
\text { structure }\end{array}$ & $\begin{array}{l}\text { production in low-level } \\
\text { containment }\end{array}$ & $\begin{array}{l}\text { relatively low } \\
\text { immunogenicity }\end{array}$ \\
\hline Inactivated virus vaccine & whole virus treated by heat or chemicals & affordability and safety & $\begin{array}{l}\text { biosafety level } 3 \\
\text { containment required }\end{array}$ \\
\hline Live attenuated vaccine & $\begin{array}{l}\text { live virus with deleted or mutated virulence } \\
\text { gene }\end{array}$ & strong immunogenicity & $\begin{array}{l}\text { potential virulence } \\
\text { reversion }\end{array}$ \\
\hline
\end{tabular}


lines, including lower respiratory, kidney, intestinal, and liver cells, are susceptible to MERS-CoV, which indicates its wide organ tropism (Oboho et al., 2015). In addition, MERS-CoV can infect immune cells such as dendritic cells and macrophages to interfere with the immune response (Chu et al., 2014; Zhou et al.,2014). Because of the high level of CD26 in T cells, MERS-CoV is able to infect T cells and inhibit their antiviral activity through the induction of $\mathrm{T}$ cell apoptosis (Chu et al., 2016; Yeung et al., 2016). MERSCoV may also suppress the innate immune response by delaying the induction of proinflammatory cytokines (Chan et al., 2013; Liu et al., 2017).

\section{Vaccines}

There are currently no available commercialized vaccines against MERS-CoV. Although some candidate vaccines are under clinical study, the majority are at the preclinical stage. There are many platforms for the development of MERS-CoV vaccines, including viral vector vaccines, DNA vaccines, inactivated vaccines, virus-like particle (VLP) vaccines, subunit vaccines, and live attenuated vaccines (Table 1 ).

\section{Viral vector-based vaccines}

A viral vector vaccine can induce antigen expression in host cells by transfer of target genes, there by activating both cell-mediated and humoral immune responses. In addition, unlike subunit vaccines, the use of an adjuvant is not necessary to improve their efficacy (Ura et al., 2014). Adenovirus and modified vaccinia ankara (MVA) have been widely used as viral vectors to develop vaccines against MERS-CoV.

Several adenovirus vector vaccines have been tested in mice. For example, a genetically engineered human adenovirus (rAd5 or rAd41) encoding full-length S protein induced mucosal immunity and neutralizing antibodies in intramuscularly immunized mice (Guo et al., 2015). In $\mathrm{BALB} / \mathrm{c}$ mice, a recombinant adenovirus (rAd5) expressing the $S 1$ domain of the $S$ protein elicited stronger neutralizing antibodies than one encoding the full-length $S$ protein (Kim et al., 2014). In a recent study, a recombinant adenoviral vector encoding CD40-targeted S1 fusion protein (rAd5-S1/F/CD40L) totally protected hDPP4-transgenic mice against MERS-CoV challenge (Hashem et al., 2019). In addition, prime-boost immunization with an adenovirus vector encoding $S$ protein plus $S$ protein nanoparticles stimulated both Th1 and Th2 immune responses in BALB/c mice (Jung et al., 2018).

A human adenoviral vector vaccine may not be effective because of preexisting immunity to the vector virus
(Fausther-Bovendo and Kobinger, 2014). For this reason, a new chimpanzee adenoviral vector (ChAdOxl) was developed to avoid such preexisting immunity (Dicks et al. 2012). Recombinant ChAdOxl encoding S protein proved immunogenic in mice and protected hDPP4-transgenic mice against virus challenge (Alharbi et al., 2017; Munster et al., 2017). A phase I study of MERS001, which comprises ChAdOxl expressing $S$ protein, is in progress in the United Kingdom. This study will evaluate the safety and immunogenicity of MERSO01 in healthy adult volunteers.

The MVA viral vector is another attractive candidate for developing a MERS-CoV vaccine. Recombinant MVA encoding $S$ protein was demonstrated to be safe and immunogenic, providing protection against MERS-CoV (Song et al., 2013; Volz et al., 2015). A phase I study of MVA-MERS-S in Germany will assess its safety and immunogenicity in healthy adult volunteers.

The viral vector platform is promising because it can stimulate strong immune responses. However, there are some disadvantages, including preexisting immunity, potential pathogenicity, low production yield, and risk of tumorigenesis (Ura et al., 2014).

\section{DNA vaccines}

A DNA vaccine is a recombinant plasmid encoding a viral antigen that is transferred into host cells by injection, gene gun, or electroporation, resulting in expression of antigen in the body and the induction of an immune response (Ferraro et al., 2011). The advantages of DNA vaccines are their simple manufacturing process and low production cost (Leitner et al., 1999). Targets of potential DNA vaccines against MERS-CoV are the S protein or its S1 domain. DNA encoding the $S$ protein has been shown to elicit neutralizing antibodies and strong cellular immunity in mice and macaques. For example, macaques immunized with DNA vaccines were protected against MERS-CoV challenge (Muthumani et al., 2015). A phase I study confirmed the safety and immunogenicity of the GLS-5300 DNA vaccine in healthy adults (Modjarrad et al., 2019), and phase I and II studies are in progress in South Korea to evaluate its safety and immunogenicity. Although DNA vaccines are thought to be effective, there is a potential risk of plasmid integration into the host genome, although the probability of this is very low (Ledwith et al., 2000).

\section{Subunit vaccines}

Subunit vaccines are known to be safe, but their immunogenicity is relatively low (Du et al., 2016). The S protein of MERS-CoV is the major target for the development of a MERS-CoV vaccine. However, an S protein-based vac- 
cine may induce non-neutralizing antibodies, resulting in a detrimental immune response (Du and Jiang, 2015). For this reason, RBD-based vaccine is preferred because it elicits RBD-specific neutralizing antibodies and may avoid the production of non-neutralizing antibodies.

To overcome the low immunogenicity of subunit vaccines, an adjuvant is required in the vaccine formulation. For example, an S1 protein-based vaccine with an MF59 adjuvant protected hDPP4-transgenic mice against lethal challenge and also induced neutralizing antibodies (Wang et al., 2017). Another study showed that S1 proteins combined with other adjuvants decreased viral shedding in dromedary camels and provided protection against MERS-CoV challenge in alpacas (Adney et al., 2019).

RBD-based vaccines in the form of fusion proteins have also been investigated in an effort to increase the immune response. A fusion protein of RBD with the Fc fragment of human IgG (RBD-Fc) induced robust neutralizing antibodies in mice (Nyon et al., 2018) and New Zealand white rabbits (Ma et al., 2014b). Another study showed that RBD-Fc immunization effectively protected hDPP4transgenic mice against virus challenge (Ma et al., 2014a). RBD-Fc combined with an adjuvant was also reported to have better immunogenicity and to induce protection in a mouse challenge model (Zhang et al., 2016). In addition, the inclusion of multiple adjuvants in RBD-based vaccines had a synergistic effect on their immunogenicity. Immunization with RBD protein combined with both alum and CpG ODN induced higher immune responses in mice than immunization with RBD antigen and a single adjuvant (Lan et al., 2014). An RBD-based vaccine containing alum was also tested in rhesus macaques. It elicited strong humoral and cellular immune responses and provided partial protection against virus challenge (Lan et al., 2015).

The use of a recombinant trimeric $S$ protein mimicking the native $S$ protein of MERS-CoV was also reported (Pallesen et al., 2017). The trimeric form was synthesized using foldon (Fd), which is a T4 fibritin trimerization domain. This S-protein trimer elicited robust neutralizing antibodies in immunized BALB/c mice and showed high efficacy against viral challenge in hDPP4-transgenic mice (Tai et al., 2016).

\section{VLP-based vaccines}

VLPs are nanoparticles that resemble the native virus structure, but do not contain infectious genetic components. For this reason, they are not infectious and cannot reproduce themselves. VLPs have self-assembly characteristics and consist of repetitive proteins. Because live virus is not required in the manufacturing process, VLP can be produced easily in a low-level containment facil- ity (DeZure et al., 2016). The structure of a VLP vaccine is similar to that of an inactivated virus vaccine. However, unlike inactivated vaccines, VLP vaccine production does not require an inactivation step that may affect the immunogenicity of a virus antigen.

In a previous study, VLPs of S, E, and M proteins were expressed using a baculovirus system. They were indistinguishable from native virus particles by electron microscopy. When they were administered with alum, they induced neutralizing antibodies and a Th1 immune response in rhesus macaques (Wang et al., 2017). In another study, immunization with nanoparticles of $S$ protein with alum elicited an antibody response in mice. When mice were vaccinated with a Matrix M1 adjuvant instead of alum, a higher neutralizing antibody titer was reported, and immunization with S-protein nanoparticles combined with Matrix M1 protected hDPP4-transgenic mice against MERS-CoV challenge (Coleman et al., 2014)

\section{Inactivated virus vaccines}

Inactivated virus vaccines contain the whole virion that has been inactivated by heat or chemicals. The advantages of an inactivated virus vaccine are its low production cost, acceptable safety profile, and simple manufacturing process (DeZure et al., 2016). However, the live virus must be handled in high-level containment, and the virus inactivation step may change the properties of the antigen (DeZure et al., 2016).

A formaldehyde-inactivated vaccine elicited neutralizing antibodies in immunized mice. When this vaccine was administered with multiple adjuvants, it provided protection against MERS-CoV in hDPP4-transgenic mice (Deng et al., 2018). Another study developed a divalent inactivated vaccine targeted to rabies virus (RABV) and MERS-CoV. This vaccine (BNSP333-S1) consists of a fusion protein containing the MERS-CoV S1 domain and RABV G protein. BNSP333-S1 induced strong neutralizing antibody responses against $S 1$ and $\mathrm{G}$ proteins. In addition, protection against MERS-CoV challenge was demonstrated in hDPP4-transgenic mice (Wirblich et al., 2017). However, the potential risk of a pathological lung reaction after MERS-CoV challenge in hDPP4-transgenic mice was reported (Agrawal et al., 2016)

\section{Live-attenuated vaccines}

A live-attenuated vaccine can induce similar immune responses to those induced by natural virus infection and is considered an effective type of vaccine. This type of vaccine is developed by the deletion or mutation of the viral virulence genes. A live-attenuated vaccine does not require an adjuvant because of its strong immunogenicity, 
and in most cases, a single dose is sufficient to induce a robust immune response. However, it has some disadvantages, including the potential for virulence reversion and the requirement for cold-chain storage. In addition, this type of vaccine may not be suitable for certain groups, such as infants, immunocompromised persons, and older people (Lauring et al., 2010).

A live-attenuated MERS-CoV was generated by deleting the E gene of MERS-CoV (rMERS-CoV-DE).rMERS-CoV-DE is considered to be a safe vaccine candidate because the deletion of the $\mathrm{E}$ gene prevents the risk of reversion to virulence (Almazan et al., 2013). A live-attenuated MERSCoV with a mutation of NSP16 (D130A) provided protective immunity in a mouse-adapted MERS-CoV challenge model (Menachery et al., 2017).

Recombinant measles virus (MV) is an alternative platform for a live-attenuated MRES-CoV vaccine. The recombinant MV encoding the full-length CoV S protein $\left(\mathrm{MV}_{\text {vac } 2}-\mathrm{CoV}-\mathrm{S}\right)$ elicited neutralizing antibodies and cellular immunity and provided protection against MERS-CoV challenge in hDPP4-transgenic mice (Malczyk et al., 2015). In another study, recombinant vesicular stomatitis virus (VSV) expressing the S protein of MERS-CoV was reported to induce both humoral and cellular immune responses in a rhesus macaque model (Liu et al., 2018).

\section{Diagnostics}

According to WHO and CDC guidelines, laboratory confirmation of MERS-CoV can be provided using nucleic acid amplification testing (NAAT) or serology methods. NAAT is considered the gold standard to detect MERS-CoV because of its high sensitivity and specificity. However, serology testing can be used when NAAT is unavailable. In addition, assays to detect MERS-CoV antigens have been developed for the diagnostics of MERS-CoV in camels.

\section{NAAT}

Various assays based on reverse transcription-PCR (RT-PCR) have been developed to detect MERS-CoV RNA. For example, an assay targeting the upstream $\mathrm{E}$ protein (upE) and ORFla demonstrated high sensitivity (Corman et al.,2012a; Corman et al.,2014b). The RealStar MERS-CoV RT-PCR kit that detects upE and ORFla was validated using samples from MERS patients (Corman et al., 2014b). The kit acquired WHO approval and an Emergency Use Authorization (EUA) by the US Food and Drug Administration. Other assays for sequencing the RdRp (RdRpSeq assay) or N (NSep assay) genes have been developed and used as confirmatory tests by the WHO (Corman et al., 2012b).
Apart from the RealStar MERS-CoV RT-PCR kit, other commercial kits targeting upE and ORFla were evaluated using specimens from MERS patients during the outbreak in South Korea (Kim et al.,2016). All of these assays demonstrated satisfactory sensitivity and specificity for MERSCoV confirmation (Kim et al., 2016). In another study, an RT-PCR assay detecting the S-protein gene was tested on clinical samples and showed similar accuracy to the RT-PCR assays targeting upE and ORFla (Lee et al., 2017). Loop-mediated isothermal amplification RT-PCR assays (RT-LAMP) were developed to permit rapid detection of MERS-CoV using portable instruments (Bhadra et al., 2015). Novel RT-PCR assays targeting the leader sequences of MERS-CoA were confirmed to have comparable sensitivity and specificity to those of the commercial RT-PCR assays (Chan et al., 2015a).

\section{Antigen detection test}

Although NAAT is a highly sensitive and specific technique for detecting MERS-CoV, it is costly and timeconsuming for screening for MERS-CoV in large numbers of samples. For this reason, an immunochromatographic assay was developed to detect MERS-CoV antigens in dromedary camels (Song et al., 2015). The assay, which targets the $\mathrm{N}$ protein using monoclonal antibodies, demonstrated similar high sensitivity and specificity to RT-PCR detecting upE and ORFla for identifying virus in specimens from camels (Song et al., 2015). In another study, an enzyme-linked immunosorbent assay (ELISA) using two N protein-specific monoclonal antibodies (MAbs) was evaluated in clinical samples (Chen et al., 2015). The advantage of the antigen detection assays is that they are inexpensive and user-friendly compared with the RT-PCR method. However, they need to be validated in human samples and improved in terms of their sensitivity (Chan et al., 2017).

\section{Antibody detection test}

The main target of serological assays are anti-MERSCoV antibodies specific for $\mathrm{N}$ protein or S protein. The advantages of serological assays over NAAT are their shorter assay time, easier handling, and affordability (Fukushi et al., 2018; Trivedi et al., 2018). However, the drawback of these assays is the risk of cross-reactivity with other coronaviruses, such as SARS-CoV (Meyer et al., 2014).

ELISA, indirect immunofluorescence testing(IIFT), and neutralization testing are the major types of serological assays used to detect antibodies against MERS-CoV. Most ELISA assays contain specific monoclonal antibodies to capture the antigens. IIFT can be used to detect a wide range of antigens, and microscopic observation is possi- 
Table 2. The comparison of MERS-CoV diagnostics

\begin{tabular}{llll}
\hline Method & Target & Advantage & Disadvantage \\
\hline NAAT & upE and ORFla of MERS-CoV RNA & high sensitivity and specificity & $\begin{array}{l}\text { high cost and biosafety level 3 } \\
\text { laboratory required } \\
\text { Neutralization }\end{array}$ \\
& activity of MERS-CoV antibodies & high sensitivity and specificity & $\begin{array}{l}\text { labor intensive, time-consuming, and } \\
\text { handling of live virus }\end{array}$ \\
ELISA & $\begin{array}{l}\text { antibodies against MERS-CoV N or S } \\
\text { protein }\end{array}$ & low cost and short assay time & possible cross-reactivity \\
RDT & MERS-CoV antibodies & simple and fast results & low sensitivity \\
\hline
\end{tabular}

ble. Neutralization tests evaluate the activity of antibodies against MERS-CoV through the inhibition of virus infectivity (Perera et al., 2013), and include plaque-reduction neutralization tests (PRNT), microneutralization (MN), and pseudoparticle-neutralization tests. The drawbacks of $\mathrm{MN}$ are that it is labor intensive and has a long process time. In addition, both PRNT and MN require high-level containment because they involve the handling of live viruses (Hemida et al., 2014).

An ELISA assay targeting MERS-CoV S1 IgG was evaluated and compared with MERS-CoV RNA detection in patient samples during an outbreak in the KSA. The results of ELISA and NAAT showed little correlation, which suggested that MERS-CoV IgG detection may not be suitable for detecting MERS-CoV infection (Alhetheel et al., 2017). Nevertheless, both the WHO and CDC have approved serological methods for the confirmation of MERS cases. Another study showed that the sensitivity and specificity of these methods can be increased by screening using indirect ELISAs targeting $\mathrm{N}$ and $\mathrm{S}$ proteins and confirmation by $\mathrm{MN}$ assay (Trivedi et al., 2018). Another group reported that a competitive ELISA using labeled MAbs against MERS-CoV effectively detected MERS-CoV-specific antibodies in animal serum. This assay was also validated using camel serum and demonstrated a strong correlation with the MN assay (Fukushi et al., 2018). Lee et al. developed two ELISA systems for detecting MERS-CoV antigens and antibodies against MERS-CoV. These systems could detect MERSCoV-specific antibodies in animal sera and the sera of patients with MERS.

A rapid diagnostic test (RDT) using specific antibodies was developed to detect MERS-CoV in camels (Song et al., 2015). The advantages of the RDT are its short assay time and easy manipulation with minimal training. However, its sensitivity is much lower than that of ELISA, and follow-up confirmatory testing should be performed (Chen et al., 2016).The various methods used to detect MERS-CoV are summarized in Table 2.

\section{Conclusions}

Since MERS-CoV was first isolated in 2012, considerable research has been performed to understand the mechanisms of MERS-CoV transmission and infection. The $S$ protein or RBD domain of the virus is considered the main targets for vaccine development because of their crucial role in virus entry into host cells. However, no vaccine against MERS has been approved, and only three candidates (two viral vector-based vaccines and one DNA vaccine) are in human clinical trials. For this reason, the early detection of MERS-CoV is crucially important for stopping the spread of this serious disease. NAAT and serology assays are widely used for the confirmation of MERS-CoV.NAAT is the gold standard for the diagnosis of MERS-CoV because of its high sensitivity and specificity. However, the assay is costly and requires high-level containment because of the handling of live viruses. Serology assays such as ELISA are affordable, and their assay time is shorter than that of NAAT, even though their sensitivity is relatively lower. Recent studies suggest that a costeffective assay with high sensitivity will be developed and validated in human samples in the near future.

Acknowledgments. We acknowledge the excellent discussion provided by the members of the Laboratory of Viral Immunology. This work was supported by the Korean Health Technology $R \& D$ Project through the Korea Health Industry Development Institute (KHIDI), the Ministry of Health \& Welfare, Republic of Korea (HI15C2955); the Basic Science Research Program through the National Research Foundation(NRF) funded by the Ministry of Science, ICT \& Future Planning (NRF-2015M3A9B5030157); a grant (20172MFDS290) from Ministry of Food and Drug Safety in 2020; the Catholic University of Korea, Research Fund, 2020

\section{References}

Adney, DR, Wang L, van Doremalen, N, Shi, W, Zhang, Y, Kong WP, Miller, MR, Bushmaker, T, Scott, D, de Wit, E, Modjarrad, K, Petrovsky, N, Graham, BS, Bowen, RA, 
and Munster, VJ., Viruses 11, 212, 2019. https://doi. org/10.3390/v11030212

Agrawal, AS, Tao, X, Algaissi, A, Garron, T, Narayanan, K, Peng, BH, Couch, RB, Tseng, CT., Hum. Vaccin. Immunother. 12, 2351-2356, 2016. https://doi.org/10.1080/21645515. 2016.1177688

Al-Abdallat, MM, Payne, DC, Alqasrawi, S, Rha, B, Tohme, RA, Abedi, GR, Al Nsour, M, Iblan, I, Jarour, N, Farag, NH, Haddadin, A, Al-Sanouri, T, Tamin, A, Harcourt, JL, Kuhar, DT, Swerdlow, DL, Erdman, DD, Pallansch, MA, Haynes, LM, Gerber, SI, Jordan, M-CIT., Clin. Infect. Dis. 59, 1225-33, 2014.

Alharbi, NK, Padron-Regalado, E, Thompson, CP, Kupke, A, Wells, D, Sloan, MA, Grehan, K, Temperton, N, Lambe, T, Warimwe, G, Becker, S, Hill, AVS, Gilbert, SC., Vaccine 35, 3780-3788, 2017. https://doi.org/10.1016/j.vaccine.2017.05.032

Alhetheel, A, Altalhi, H, Albarrag, A, Shakoor, Z, Mohamed, D, El-Hazmi, M, Somily, A, Barry, M, Bakhrebah, M, Nassar, M., Viral. Immunol. 30, 649-653, 2017. https://doi. org/10.1089/vim.2017.0091

Almazan, F, DeDiego, ML, Sola, I, Zuniga, S, Nieto-Torres, JL, Marquez-Jurado, S, Andres, G, Enjuanes, L., MBio 4, e00650-13, 2013.https://doi.org/10.1128/mBio.00650-13

Alshukairi, AN, Zheng, J, Zhao, J, Nehdi, A, Baharoon, SA, Layqah, L, Bokhari, A, Al Johani, SM, Samman, N, Boudjelal, M, Ten Eyck, P, Al-Mozaini, MA, Zhao, J, Perlman, S, Alagaili, AN., (2018): High Prevalence of MERS-CoV Infection in Camel Workers in Saudi Arabia. MBio 9, e01985-18, 2018. https://doi.org/10.1128/mBio.01985-18

Assiri, A, McGeer, A, Perl, TM, Price, CS, Al Rabeeah, AA, Cummings, DA, Alabdullatif, ZN, Assad, M, Almulhim, A, Makhdoom, H, Madani, H, Alhakeem, R, Al-Tawfiq, JA, Cotten, M, Watson, SJ, Kellam, P, Zumla, AI, Memish, ZA, Team, KM-CI., N. Engl. J. Med. 369, 407-416, 2013. https://doi.org/10.1056/NEJMoa1306742

Bhadra, S, Jiang, YS, Kumar, MR, Johnson, RF, Hensley, LE, Ellington, AD., PLoS One 10, e0123126, 2015. https://doi. org/10.1371/journal.pone.0123126

Chan, JF, Choi, GK, Tsang, AK, Tee, KM, Lam, HY, Yip, CC, To, KK, Cheng, VC, Yeung, ML, Lau, SK, Woo, PC, Chan, KH, Tang, BS, Yuen, KY., J. Clin. Microbiol. 53, 2722-2726, 2015a. https://doi.org/10.1128/JCM.01224-15

Chan, JF, Lau, SK, To, KK, Cheng, VC, Woo, PC, Yuen, KY., Clin. Microbiol. Rev.28,465-522,2015b.https://doi.org/10.1128/ CMR.00102-14

Chan, JF, Sridhar, S, Yip, CC, Lau, SK, Woo, PC., J. Microbiol. 55, 172-182,2017. https://doi.org/10.1007/s12275-017-7026-y

Chan, RW, Chan, MC, Agnihothram, S, Chan, LL, Kuok, DI, Fong, JH, Guan, Y, Poon, LL, Baric, RS, Nicholls, JM, Peiris, JS., J.Virol. 87, 6604-6614, 2013. https://doi.org/10.1128/ JVI.00009-13

Chen, Y, Chan, KH, Hong, C, Kang, Y, Ge, S, Chen, H, Wong, EY, Joseph, S, Patteril, NG, Wernery, U, Xia, N, Lau, SK, Woo, PC., J. Infect. 73, 82-84, 2016. https://doi.org/10.1016/j. jinf.2016.04.014
Chen, Y, Chan, KH, Kang, Y, Chen, H, Luk, HK, Poon, RW, Chan, JF, Yuen, KY, Xia, N, Lau, SK, Woo, PC., Emerg. Microbe. Infect. 4, e26,2015. https://doi.org/10.1038/emi.2015.26

Chu, H, Zhou, J, Wong, BH, Li, C, Chan, JF, Cheng, ZS, Yang, D, Wang, D, Lee, AC, Li, C, Yeung, ML, Cai, JP, Chan, IH, Ho, WK, To, KK, Zheng, BJ, Yao, Y, Qin, C, Yuen, KY., J. Infect. Dis. 213, 904-914, 2016. https://doi.org/10.1093/ infdis/jiv380

Chu, H, Zhou, J, Wong, BH, Li, C, Cheng, ZS, Lin, X, Poon, VK, Sun, T, Lau, CC, Chan, JF, To, KK, Chan, KH, Lu, L, Zheng, BJ, Yuen, KY., Virology 454-455, 197-205, 2014. https://doi. org/10.1016/j.virol.2014.02.018

Coleman, CM, Liu, YV, Mu, H, Taylor, JK, Massare, M, Flyer, DC, Smith, GE, Frieman, MB., Vaccine 32, 3169-3174, 2014. https://doi.org/10.1016/i.vaccine.2014.04.016

Corman, VM, Eckerle, I, Bleicker, T, Zaki, A, Landt, O, EschbachBludau, M, van Boheemen, S, Gopal, R, Ballhause, M, Bestebroer, TM, Muth, D, Muller, MA, Drexler, JF, Zambon, M, Osterhaus, AD, Fouchier, RM, Drosten, C., Euro. Surveill.17,20285,2012a.https://doi.org/10.2807/ ese.17.39.20285-en

Corman, VM, Ithete, NL, Richards, LR, Schoeman, MC, Preiser, W, Drosten, C, Drexler, JF., J. Virol. 88, 11297-11303, 2014 a. https://doi.org/10.1128/JVI.01498-14

Corman, VM, Muller, MA, Costabel, U, Timm, J, Binger, T, Meyer, B, Kreher, P, Lattwein, E, Eschbach-Bludau, M, Nitsche, A, Bleicker, T, Landt, O, Schweiger, B, Drexler, JF, Osterhaus, AD, Haagmans, BL, Dittmer, U, Bonin, F, Wolff, T, Drosten, C., Euro. Surveill.17,20334, 2012b. https://doi. org/10.2807/ese.17.49.20334-en

Corman, VM, Olschlager, S, Wendtner, CM, Drexler, JF, Hess, M, Drosten, C., J. Clin. Virol.60,168-171, 2014b. https://doi. org/10.1016/j.jcv.2014.03.012

Deng, Y, Lan, J, Bao, L, Huang, B, Ye, F, Chen, Y, Yao, Y, Wang, W, Qin, C, Tan, W., Emerg. Microbes. Infect. 7, 60, 2018. https://doi.org/10.1038/s41426-018-0056-7

DeZure, AD, Berkowitz, NM, Graham, BS, Ledgerwood, JE., J. Infect. Dis. 214, S497-S499, 2016. https://doi.org/10.1093/ infdis/jiw352

Dicks, MD, Spencer, AJ, Edwards, NJ, Wadell, G, Bojang, K, Gilbert, SC, Hill, AV, Cottingham, MG., PLoS One 7, e40385, 2012. https://doi.org/10.1371/journal.pone.0040385

Du, L, Jiang, S., Expert. Opin. Biol. Ther. 15, 1647-1651, 2015.

Du, L, Tai, W, Zhou, Y, Jiang, S., Expert. Rev. Vaccines 15, 1123-34, 2016. https://doi.org/10.1586/14760584.2016.1167603

Fausther-Bovendo, H, Kobinger, GP., Hum. Vaccin. Immunother. 10, 2875-84, 2014. https://doi.org/10.4161/hv.29594

Ferraro, B, Morrow, MP, Hutnick, NA, Shin, TH, Lucke, CE, Weiner, DB., Clin. Infect. Dis. 53, 296-302, 2011. https:// doi.org/10.1093/cid/cir334

Forni, D, Cagliani, R, Clerici, M, Sironi, M., Trends Microbiol.25, 35-48, 2017. https://doi.org/10.1016/j.tim.2016.09.001

Fukushi, S, Fukuma, A, Kurosu, T, Watanabe, S, Shimojima, M, Shirato, K, Iwata-Yoshikawa, N, Nagata, N, Ohnishi, K, Ato, M, Melaku, SK, Sentsui, H, Saijo, M., J. Virol. Methods 251, 22-29, 2018. https://doi.org/10.1016/i. jviromet.2017.10.008 
Guo, X, Deng, Y, Chen, H, Lan, J, Wang, W, Zou, X, Hung, T, Lu, Z, Tan, W., Immunology 145, 476-484, 2015. https://doi. org/10.1111/imm.12462

Hagemeijer, MC, Rottier, PJ, de Haan, CA., Viruses 4, 3245-3269, 2012. https://doi.org/10.3390/v4113245

Hashem, AM, Algaissi, A, Agrawal, AS, Al-Amri, SS, Alhabbab, RY, Sohrab, SS, A, SA, Alharbi, NK, Peng, BH, Russell, M, Li, X, Tseng, CK., (2019) J. Infect. Dis. 220, 1558-1567, 2019. https://doi.org/10.1093/infdis/jiz137

Hemida, MG, Perera, RA, Al Jassim, RA, Kayali, G, Siu, LY, Wang, P, Chu, KW, Perlman, S, Ali, MA, Alnaeem, A, Guan, Y, Poon, LL, Saif, L, Peiris, M., Euro. Surveill. 19, 20828, 2014. https://doi.org/10.2807/1560-7917. ES2014.19.23.20828

Ithete, NL, Stoffberg, S, Corman, VM, Cottontail, VM, Richards, LR, Schoeman, MC, Drosten, C, Drexler, JF, Preiser, W., Emerg. Infect. Dis. 19, 1697-1699, 2013. https://doi. org/10.3201/eid1910.130946

Jung, SY, Kang, KW, Lee, EY, Seo, DW, Kim, HL, Kim, H, Kwon, T, Park, HL, Kim, H, Lee, SM, Nam, JH., Vaccine 36, 3468-3476, 2018. https://doi.org/10.1016/j.vaccine.2018.04.082

Kim, E, Okada, K, Kenniston, T, Raj, VS, AlHajri, MM, Farag, EA, AlHajri, F, Osterhaus, AD, Haagmans, BL, Gambotto, A., Vaccine 32, 5975-5982, 2014. https://doi.org/10.1016/i. vaccine.2014.08.058

Kim, KH, Tandi, TE, Choi, JW, Moon, JM, Kim, MS., J Hosp Infect 95, 207-213, 2017. https://doi.org/10.1016/j. ihin.2016.10.008

Kim, MN, Ko, YJ, Seong, MW, Kim, JS, Shin, BM, Sung, H., Ann. Lab. Med. 36, 450-456, 2016. https://doi.org/10.3343/ alm.2016.36.5.450

Lan, J, Deng, Y, Chen, H, Lu, G, Wang, W, Guo, X, Lu, Z, Gao, GF, Tan, W., PLoS One 9, el12602, 2014. https://doi.org/10.1371/ journal.pone.0112602

Lan, J, Yao, Y, Deng, Y, Chen, H, Lu, G, Wang, W, Bao, L, Deng, W, Wei, Q, Gao, GF, Qin, C, Tan, W., EBio Medicine 2, 14381446, 2015.https://doi.org/10.1016/j.ebiom.2015.08.031

Lauring, AS, Jones, JO, Andino, R., Nat. Biotechnol. 28, 573-579, 2010. https://doi.org/10.1038/nbt.1635

Ledwith, BJ, Manam, S, Troilo, PJ, Barnum, AB, Pauley, CJ, Griffiths, TG, 2nd, Harper, LB, Beare, CM, Bagdon, WJ, Nichols, WW., Intervirology 43, 258-272, 2000. https:// doi.org/10.1159/000053993

Lee, JS, Ahn, JS, Yu, BS, Cho, SI, Kim, MJ, Choi, JM, Seo, SH, Park, SS, Seong, MW., J Clin. Microbiol. 55, 2554-2555, 2017. https://doi.org/10.1128/JCM.00667-17

Lee, K, Ko, HL, Lee, EY, Park, HJ, Kim, YS, Kim YS, Cho, NH, Park, MS, Lee, SM, Kim, H, Seong, BL, Nam, JH., Microbiol. Immunol. 62, 574-584, 2018. https://doi. org/10.1111/1348-0421.12643

Leitner, WW, Ying, H, Restifo, NP., Vaccine 18, 765-777, 1999. https://doi.org/10.1016/S0264-410X(99)00271-6

Liu, R, Wang, J, Shao, Y, Wang, X, Zhang, H, Shuai, L, Ge, J, Wen, Z, Bu, Z., Antiviral. Res. 150, 30-38, 2018. https://doi. org/10.1016/i.antiviral.2017.12.007
Liu, WJ, Lan, J, Liu, K, Deng, Y, Yao, Y, Wu, S, Chen, H, Bao, L, Zhang, H, Zhao, M, Wang, Q, Han, L, Chai, Y, Qi, J, Zhao, J, Meng, S, Qin, C, Gao, GF, Tan, W., J. Immunol.198, 873882, 2017. https://doi.org/10.4049/jimmunol.1601542

Ma, C, Li, Y, Wang, L, Zhao, G, Tao, X, Tseng, CT, Zhou, Y, Du, L, Jiang, S., Vaccine 32, 2100-2108, 2014a. https://doi. org/10.1016/j.vaccine.2014.02.004

Ma, C, Wang, L, Tao, X, Zhang, N, Yang, Y, Tseng, CK, Li, F, Zhou, Y, Jiang, S, Du, L., Vaccine 32, 6170-6176, 2014b. https:// doi.org/10.1016/i.vaccine.2014.08.086

Mackay, IM, Arden, KE., Virol. J. 12, 222, 2015. https://doi. org/10.1186/s12985-015-0439-5

Malczyk, AH, Kupke, A, Prufer, S, Scheuplein, VA, Hutzler, S, Kreuz, D, Beissert, T, Bauer, S, Hubich-Rau, S, Tondera, C, Eldin, HS, Schmidt, J, Vergara-Alert, J, Suzer, Y, Seifried, J, Hanschmann, KM, Kalinke, U, Herold, S, Sahin, U, Cichutek, K, Waibler, Z, Eickmann, M, Becker, S, Muhlebach, MD., J. Virol. 89,11654-11667, 2015. https:// doi.org/10.1128/JVI.01815-15

Menachery, VD, Gralinski, LE, Mitchell, HD, Dinnon, KH, 3rd, Leist, SR, Yount, BL, Jr., Graham, RL, McAnarney, ET, Stratton, KG, Cockrell, AS, Debbink, K, Sims, AC, Waters, KM, Baric, RS., mSphere 2, e00346-17, 2017. https://doi. org/10.1128/mSphere.00346-17

Meyer, B, Drosten, C, Muller, MA., Virus Res. 194, 175-183, 2014. https://doi.org/10.1016/j.virusres.2014.03.018

Millet, JK, Whittaker, GR., Proc. Natl. Acad. Sci. USA 111, 152141529, 2014. https://doi.org/10.1073/pnas.1407087111

Modjarrad, K, Roberts, CC, Mills, KT, Castellano, AR, Paolino, K, Muthumani, K, Reuschel, EL, Robb, ML, Racine, T, Oh, MD, Lamarre, C, Zaidi, FI, Boyer, J, Kudchodkar, SB, Jeong, M, Darden, JM, Park, YK, Scott, PT, Remigio, C, Parikh, AP, Wise, MC, Patel, A, Duperret, EK, Kim, KY, Choi, H, White, S, Bagarazzi, M, May, JM, Kane, D, Lee, H, Kobinger, G, Michael, NL, Weiner, DB, Thomas, SJ, Maslow, JN., Lancet Infect. Dis. 19, 1013-1022, 2019. https://doi.org/10.1016/S1473-3099(19)30266-X

Munster, VJ, Wells, D, Lambe, T, Wright, D, Fischer, RJ, Bushmaker, T, Saturday, G, van Doremalen, N, Gilbert, SC, de Wit, E, Warimwe, GM., NPJ Vaccines 2, 28, 2017. https:// doi.org/10.1038/s41541-017-0029-1

Muthumani, K, Falzarano, D, Reuschel, EL, Tingey, C, Flingai, S, Villarreal, DO, Wise, M, Patel, A, Izmirly, A, Aljuaid, A, Seliga, AM, Soule, G, Morrow, M, Kraynyak, KA, Khan, AS, Scott, DP, Feldmann, F, LaCasse, R, Meade-White, K, Okumura, A, Ugen, KE, Sardesai, NY, Kim, JJ, Kobinger, G, Feldmann, H, Weiner, DB., Sci. Transl. Med. 7, 301ra132, 2015. https://doi.org/10.1126/scitranslmed. aac7462

Neuman, BW, Chamberlain, P, Bowden, F, Joseph, J., Virus Res. 194, 49-66, 2014. https://doi.org/10.1016/i.virusres.2013.12.004

Nishiura, H, Endo, A, Saitoh, M, Kinoshita, R, Ueno, R, Nakaoka, S, Miyamatsu, Y, Dong, Y, Chowell, G, Mizumoto, K., BMJ Open 6, e009936, 2016a. https://doi.org/10.1136/ bmjopen-2015-009936 
Nishiura, H, Miyamatsu, Y, Mizumoto, K., Emerg. Infect. Dis. 22, 146-148, 2016b. https://doi.org/10.3201/eid2201.151383

Nyon, MP, Du, L, Tseng, CK, Seid, CA, Pollet, J, Naceanceno, KS, Agrawal, A, Algaissi, A, Peng, BH, Tai, W, Jiang, S, Bottazzi, ME, Strych, U, Hotez, PJ., Vaccine 36, 1853-1862, 2018. https://doi.org/10.1016/j.vaccine.2018.02.065

Oboho, IK, Tomczyk, SM, Al-Asmari, AM, Banjar, AA, Al-Mugti, H, Aloraini, MS, Alkhaldi, KZ, Almohammadi, EL, Alraddadi, BM, Gerber, SI, Swerdlow, DL, Watson, JT, Madani, TA., N. Engl. J. Med.372, 846-554, 2015. https:// doi.org/10.1056/NEJMoa1408636

Pallesen, J, Wang, N, Corbett, KS, Wrapp, D, Kirchdoerfer, RN, Turner, HL, Cottrell, CA, Becker, MM, Wang, L, Shi, W, Kong, WP, Andres, EL, Kettenbach, AN, Denison, MR, Chappell, JD, Graham, BS, Ward, AB, McLellan, JS., Proc. Natl. Acad. Sci. USA.114, E7348-E7357,2017. https://doi. org/10.1073/pnas.1707304114

Park, HY, Lee, EJ, Ryu, YW, Kim, Y, Kim, H, Lee, H, Yi, SJ., Euro. Surveill.20,1-6,2015. https://doi.org/10.2807/1560-7917. ES2015.20.25.21169

Perera, RA, Wang, P, Gomaa, MR, El-Shesheny, R, Kandeil, A, Bagato, O, Siu, LY, Shehata, MM, Kayed, AS, Moatasim, Y, Li, M, Poon, LL, Guan, Y, Webby, RJ, Ali, MA, Peiris, JS, Kayali, G., Euro. Surveill.18, 20574,2013. https://doi. org/10.2807/1560-7917.ES2013.18.36.20574

Qian, Z, Dominguez, SR, Holmes, KV., PLoS One 8, e76469, 2013. https://doi.org/10.1371/journal.pone.0076469

Raj, VS, Mou, H, Smits, SL, Dekkers, DH, Muller, MA, Dijkman, R, Muth, D, Demmers, JA, Zaki, A, Fouchier, RA, Thiel, V, Drosten, C, Rottier, PJ, Osterhaus, AD, Bosch, BJ, Haagmans, BL., Nature 495, 251-254, 2013. https://doi. org/10.1038/nature12005

Song, D, Ha, G, Serhan, W, Eltahir, Y, Yusof, M, Hashem, F, Elsayed, E, Marzoug, B, Abdelazim, A, Al Muhairi, S., J. Clin. Microbiol. 53, 1178-1182, 2015. https://doi.org/10.1128/ JCM.03096-14

Song, F, Fux, R, Provacia, LB, Volz, A, Eickmann, M, Becker, S, Osterhaus, AD, Haagmans, BL, Sutter, G., J. Virol. 87, 11950-4, 2013. https://doi.org/10.1128/JVI.01672-13

Tai, W, Zhao, G, Sun, S, Guo, Y, Wang, Y, Tao, X, Tseng, CK, Li, F, Jiang, S, Du, L, Zhou, Y., Virology 499, 375-382, 2016. https://doi.org/10.1016/j.virol.2016.10.005
Trivedi, S, Miao, C, Al-Abdallat, MM, Haddadin, A, Alqasrawi, S, Iblan, I, Nsour, MA, Alsanouri, T, Ali, SS, Rha, B, Gerber, SI, Payne, DC, Tamin, A, Thornburg, NJ., J. Med. Virol. 90, 367-371, 2018. https://doi.org/10.1002/imv.24948

Ura, T, Okuda, K, Shimada, M., Vaccines (Basel) 2, 624-641, 2014. https://doi.org/10.3390/vaccines2030624

Volz, A, Kupke, A, Song, F, Jany, S, Fux, R, Shams-Eldin, H, Schmidt, J, Becker, C, Eickmann, M, Becker, S, Sutter, G., J.Virol. 89, 8651-8656, 2015. https://doi.org/10.1128/ JVI.00614-15

Wang, Y, Sun, J, Zhu, A, Zhao, J, Zhao, J., J. Thorac. Dis. 10, S2260S2271, 2018. https://doi.org/10.21037/jtd.2018.03.80

Wang, Y, Tai, W, Yang, J, Zhao, G, Sun, S, Tseng, CK, Jiang, S, Zhou, Y, Du, L, Gao, J., Hum. Vaccin. Immunother. 13, 1615-1624, 2017. https://doi.org/10.1080/21645515.201 7.1296994

Widagdo, W, Raj, VS, Schipper, D, Kolijn, K, van Leenders, G, Bosch, BJ, Bensaid, A, Segales, J, Baumgartner, W, Osterhaus, A, Koopmans, MP, van den Brand, JMA, Haagmans, BL., J. Virol. 90, 4838-4842, 2016. https:// doi.org/10.1128/JVI.02994-15

Wirblich, C, Coleman, CM, Kurup, D, Abraham, TS, Bernbaum, JG, Jahrling, PB, Hensley, LE, Johnson, RF, Frieman, MB, Schnell, MJ., J. Virol. 91, e02040-16, 2017. https:// doi.org/10.1128/JVI.02040-16

Yang, Y, Liu, C, Du, L, Jiang, S, Shi, Z, Baric, RS, Li, F., J. Virol. 89, 9119-9123, 2015. https://doi.org/10.1128/JVI.01279-15

Yeung, ML, Yao, Y, Jia, L, Chan, JF, Chan, KH, Cheung, KF, Chen, H, Poon, VK, Tsang, AK, To, KK, Yiu, MK, Teng, JL, Chu, H, Zhou, J, Zhang, Q, Deng, W, Lau, SK, Lau, JY, Woo, PC, Chan, TM, Yung, S, Zheng, BJ, Jin, DY, Mathieson, PW, Qin, C, Yuen, KY., Nat. Microbiol.1, 16004, 2016. https:// doi.org/10.1038/nmicrobiol.2016.4

Zaki, AM, van Boheemen, S, Bestebroer, TM, Osterhaus, AD, Fouchier, RA., N. Engl. J. Med. 367, 1814-1820, 2012. https://doi.org/10.1056/NEJMoa1211721

Zhang, N, Channappanavar, R, Ma, C, Wang, L, Tang, J, Garron, T, Tao, X, Tasneem, S, Lu, L, Tseng, CT, Zhou, Y, Perlman, S, Jiang, S, Du, L., Cell. Mol. Immunol.13,180-190, 2016. https://doi.org/10.1038/cmi.2015.03

Zhou, J, Chu, H, Li, C, Wong, BH, Cheng, ZS, Poon, VK, Sun, T, Lau, CC, Wong, KK, Chan, JY, Chan, JF, To, KK, Chan, KH, Zheng, BJ, Yuen, KY., J. Infect. Dis. 209, 1331-1342, 2014. https://doi.org/10.1093/infdis/jit504 